\title{
Effect of High Stocking Rates on Growth and Survival of the Endangered Rio Grande Silvery Minnow Hybognathus amarus
}

\author{
Alison M. Hutson, Louie A. Toya and Douglas Tave* \\ Los Lunas Silvery Minnow Refugium, New Mexico Interstate Stream Commission, Los Lunas, NM 87031, USA
}

\begin{abstract}
The endangered Rio Grande silvery minnow Hybognathus amarus was cultured in 2.44-m-diameter outdoor tanks in a 131-day yield trial to assess growth, survival, and percentage of taggable-sized fish ( $\geq 35 \mathrm{~mm}$ total length) when stocked at 500/tank (1.07 million/ha), 1,000/tank (2.14 million/ha), and 1,500/tank (3.21 million/ha). At harvest, fish averaged $45.6 \mathrm{~mm}$ and $0.94 \mathrm{~g}$ in the $500 /$ tank treatment, $42.6 \mathrm{~mm}$ and $0.74 \mathrm{~g}$ in the 1,000/tank treatment, and $38.4 \mathrm{~mm}$ and $0.55 \mathrm{~g}$ in the $1,500 /$ tank treatment; the differences were significant $(P=0.05)$. Survival in the three treatments was $70 \%, 64 \%$, and $52 \%$, respectively, but the differences were not significant. Percent taggable-sized fish was $86 \%, 89 \%$, and $65 \%$, respectively, but the differences were not significant. Yield was $672.5 \mathrm{~kg} / \mathrm{ha}, 1,026.6 \mathrm{~kg} / \mathrm{ha}$, and $887.8 \mathrm{~kg} / \mathrm{ha}$, respectively; yield in the 1,000/tank treatment was significantly greater than that in the 500/tank treatment, but was not significantly greater than that of the $1,500 /$ tank treatment. This facility is a conservation facility and a major goal is to raise fish without formulated feed. Fertilization produced good growth for the first month, but little growth occurred during the second month so supplemental feed had to be used for the final $60 \mathrm{~d}$ of the yield trial.
\end{abstract}

Key words: Rio Grande silvery minnow. Hybognathus amarus, Yield trial

\section{Introduction}

The Los Lunas Silvery Minnow Refugium is a conservation hatchery that propagates the endangered Rio Grande silvery minnow Hybognathus amarus (Tave et al., 2011). An aboveground tank unit composed of fifteen 2.44-m-diameter circular tanks was recently installed (Tave et al., 2012) to enable research projects that can answer specific questions about the species' life history, their physiological response to environmental stressors, or to provide other information that could help in recovery of the species.

Optimal stocking density, as well as growth and survival, of this species in small units are not known. This information is needed for two reasons: First, it is important to know how many fish should be stocked in the tanks to produce growth rates similar to that achieved in the conservation production unit at the facility (Tave et al., 2011; Hutson et al., 2012).
Secondly, this information will enable us to use survivors of future studies during annual augmentation of the Rio Grande. Fish produced at this facility are stocked in the Middle Rio Grande, which contains the only existing natural population of Rio Grande silvery minnow (U.S. Fish and Wildlife Service, 2010). All hatchery-produced Rio Grande silvery minnow that are stocked in the Middle Rio Grande must be tagged, so that hatchery-produced fish can be distinguished from wild fish when the river population is sampled. Hatchery-produced fish are injected with a visible implant elastomer tag (Northwest Marine Technology, Shaw Island, WA, USA), and target size for taggable fish is $\geq 35 \mathrm{~mm}$ total length (TL). Consequently, this study was designed to determine growth rates, percent survival, and percent taggable-sized fish that can be produced under higher stocking rates than is typically used to culture
http://dx.doi.org/10.5657/FAS.2013.0285

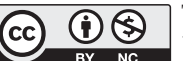

This is an Open Access article distributed under the terms of the Creative Commons Attribution Non-Commercial Licens (http://creativecommons.org/licenses/by-nc/3.0/) which permits unrestricted non-commercial use, distribution, and reproduction in any medium, provided the original work is properly cited.
Received 23 August 2013; Revised 05 November 2013

Accepted 06 November 2013

*Corresponding Author

E-mail: douglas.tave@state.nm.us 
this species.

Stocking rates used in this project were $>1,000,000 /$ ha, which is greater than that used at the two other facilities that produce Rio Grande silvery minnow for augmentation. Fish produced at Southwestern Native Aquatic Resources \& Recovery Center, Dexter, NM (M. Ulibarri and Dexter, personal communication) are stocked in 0.04- to 0.4-ha ponds at not more than 250,000/ha, and those raised at the Aquatic Conservation Unit, Albuquerque BioPark Aquarium, Albuquerque, NM (K. Ward, BioPark, personal communication) are stocked in 9.15-m-diameter tanks at 760,398/ha. These stocking densities were also greater than those that have been used to raise Rio Grande silvery minnow in the naturalized conservation unit at this facility: 90,909/ha in 2010 (Hutson et al., 2012) and 209,090/ha in 2011 (Tave and Hutson, 2011). Stocking densities $>1,000,000 /$ ha were used to determine the effects of stocking 500, 1,000, and 1,500 Rio Grande silvery minnow/2.44-m-diameter tank.

Because the Los Lunas Silvery Minnow Refugium is operated as a conservation facility, the overarching management goal during propagation is to minimize domestication (Tave et al., 2011), and a key component of management to achieve this goal is to avoid or to minimize the use of artificial feed (Hutson et al., 2012). Consequently, one goal in this project was to use fertilizers for as long as possible during this project and to feed the fish only when assessment of growth suggested that feed would be needed to produce taggable-sized fish.

The objective of this paper is to describe the results of this 131-day yield trial.

\section{Materials and Methods}

\section{Culture units}

Fish were cultured in twelve 2.44-m-diameter 0.915$\mathrm{m}$ deep circular $\left(4.278 \mathrm{~m}^{3}\right)$ above-ground fiberglass tanks. Water depth was $78.4 \mathrm{~cm}$; water volume was 3,666 L. Two $14.7 \times 3.7-\mathrm{cm}$ air diffusers were placed in each tank to provide continuous aeration. Air supply was provided by an Aquatic Eco-System Sweetwater Model S-51 air blower (Aquatic Eco-Systems, Inc., Apopka, FL, USA). Tanks were covered with $1.7-\mathrm{cm}$ mesh plastic screens. Water used in the study was Village of Los Lunas municipal water that was run through a 189 L/min Culligan Hi-Flo 42 Model HRF-30T Dechlorinator (Culligan International Co., Rosemont, IL, USA). Tanks were filled on 24 May 2012.

\section{Stocking}

Stocking rates were 500/tank (1.07 million/ha), 1,000/tank (2.14 million/ha), and 1,500/tank (3.21 million/ha). There were four replicates per treatment, and treatments were assigned randomly to each of 12 tanks. On 7 June, Dexter shipped 12,000 five-d-old 5-mm fish (Lot 12CSDX-05) in plastic bags with oxygen to the Los Lunas Silvery Minnow Refugium. Fish were hand-counted and stocked into the 12 tanks.

\section{Water quality management}

Because the Rio Grande silvery minnow is an endangered species, a major management goal is to keep water quality parameters within permitted ranges (Hutson et al., 2012). Water quality was assessed twice daily. Dissolved oxygen (DO), temperature, and $\mathrm{pH}$ were measured at dawn (ca 0600-0700) and mid-afternoon (ca 1400) seven days per week. Un-ionized ammonia was measured in the afternoon three times per week, and nitrite, alkalinity, and chloride were measured once a week in the afternoon. Hardness was measured at the beginning of the study. When the bottom of a tank was not visible, Secchi disc visibility was measured to the nearest $0.5 \mathrm{~cm}$ with a 20-cm Secchi disc each afternoon. DO and temperature were measured with a YSI 550A Dissolved Oxygen meter; $\mathrm{pH}$ was measured with a YSI pH 100 meter; all other water quality parameters were measured with a YSI 9500 Photometer (YSI, Inc., Yellow Springs, OH, USA).

Water quality was assessed twice daily from stocking until 30 August, when water quality measurements were halted due to a behavioral health issue (described below). Water quality was not assessed from 31 August until harvest (15-16 October) to avoid possible cross-contamination if the behavioral anomaly were caused by a pathogen.

The most difficult water quality parameter that must be managed at this facility is $\mathrm{pH}$. The permitted maximum $\mathrm{pH}$ is 9.0. The reason it is difficult to manage $\mathrm{pH}$ is that there is an imbalance between total alkalinity and hardness in the water used at the facility (Hutson et al., 2012; Tave et al., 2012). Alkalinity is far greater than hardness; at the beginning of the study, alkalinity was $160 \mathrm{mg} / \mathrm{L}$ and hardness was 50 $\mathrm{mg} / \mathrm{L}$. This imbalance means that afternoon $\mathrm{pH}$ can exceed 9.0 (Boyd, 1990). This can be mitigated by the addition of finely ground agricultural gypsum. When $\mathrm{pH}$ approached 9.0, agricultural gypsum was added to the tanks as described by Boyd (1990); the concentration used was twice the difference between total alkalinity and hardness, and this management technique has been successfully used to control $\mathrm{pH}$ in the naturalized outdoor refugium (Hutson et al. 2012) and in these tanks during a 30-d survival trial (Tave et al., 2012).

Agricultural gypsum was used to control $\mathrm{pH}$ from 7 June4 July; amount added per tank ranged from 4.95 to $11.55 \mathrm{~kg}$ $(10,578$ to $24,682 \mathrm{~kg} / \mathrm{ha})$. Agricultural gypsum lowers both $\mathrm{pH}$ and alkalinity and, after the 4 July application, it was determined that so much agricultural gypsum would be added to the tanks to control $\mathrm{pH}$ that alkalinity would go below its permitted minimum (100 mg/L); consequently, water exchanges were used after 4 July to manage $\mathrm{pH}$.

Prior to 4 July, water was added to the tanks to replace that 
lost to evaporation and to do four partial water exchanges: 801 $\mathrm{L}$ was added to each tank to offset evaporation, and 1,830 L was added to each tank to control $\mathrm{pH}$. Thereafter, all water that was added to the tanks was used to control $\mathrm{pH}$. Between 7 June and 6 August, there were nine water exchanges of $10 \%$, three of $20 \%$, and one of $30 \%$ per tank. Between 6 August and 15 October, there was a daily $10 \%$ water exchange per tank (a total of seventy $10 \%$ exchanges during this period).

During the yield trial, a total of 34,038 L of water added to each tank to control $\mathrm{pH}$, and $801 \mathrm{~L}$ was used to offset evaporation. This created a total water turnover of $928 \% / \operatorname{tank}$ for $\mathrm{pH}$ control and a total of $950 \% /$ tank for both $\mathrm{pH}$ control and to offset evaporation. Total water added to the tanks during the study produced a complete water turnover every 13.7 days.

\section{Fertilization}

Prior to stocking the fish, a source tank (a 2.44-m-diameter tank not used in the study) was fertilized to produce a bloom that would be used to seed all of the tanks so that all tanks would have a similar algal community. This fertilization protocol was used because it was similar to that being used in the naturalized outdoor refugium. On 23 May, the source tank was fertilized with $50 \mathrm{~mL}$ of 11-37-0 N-P-K liquid fertilizer, $60 \mathrm{~g}$ of alfalfa pellets, $7.5 \mathrm{~L}$ of water from a source tank that was being used to fertilize the naturalized outdoor refugium, and 7.5 L of water from the naturalized outdoor refugium. Refugium water was added to try to create an algal community in the tanks that was similar to that in the naturalized outdoor refugium, the conservation unit at the facility (Tave et al., 2011; Hutson et al., 2012). A dense bloom quickly developed in the source tank, but it crashed on 10 June, so it was fertilized with $10 \mathrm{~mL}$ of $11-37-0$ fertilizer, $250 \mathrm{~g}$ of alfalfa pellets, and 37.84 $\mathrm{L}$ of water from a 2.44-m-diameter tank that was part of another study to restore the algal bloom. The source tank was fertilized an additional two times that week, and twice a week for the next 12 weeks (total of 26 fertilizations over 13 weeks) with $12.5 \mathrm{~mL}$ of 11-37-0 fertilizer and $250 \mathrm{~g}$ of alfalfa pellets at each fertilization. Total fertilizer added to the source tank during the study was $345 \mathrm{~mL}$ of 11-37-0 fertilizer and $7.0 \mathrm{~kg}$ of alfalfa pellets.

On 1 June, all grow-out tanks were fertilized with $10 \mathrm{~mL}$ of 11-37-0 fertilizer, $250 \mathrm{~g}$ of alfalfa pellets, and $2 \mathrm{~L}$ of water from the source tank. Thereafter, grow-out tanks were fertilized only with water from the source tank, using the following schedule: $75.7 \mathrm{~L}$ on 14 June; $37.85 \mathrm{~L}$ twice a week for 4 weeks; $37.85 \mathrm{~L}$ three times a week for 2 weeks; $18.92 \mathrm{~L}$ daily for $19 \mathrm{~d} ; 18.92 \mathrm{~L}$ twice a week for 3 weeks. The last addition of source tank water was 9 September. A total of 1,040.9 L of source tank water was added to each grow-out tank during the yield trial.

\section{Feeding}

Feeding was started on 16 August, after the results from the second growth sample were evaluated. Fish were fed Rio Grande silvery minnow feed (Caldwell et al. 2010) at $5 \mathrm{~g} /$ tank/day (10.69 kg/ha/day) from 16-22 August. From 23-28 August, fish were fed $5 \mathrm{~g} /$ tank twice daily $(21.39 \mathrm{~kg} / \mathrm{ha} /$ day $)$. Vigorous feeding was observed in most tanks on 29 August, so feeding rate was increased and, from 29 August-14 October, fish were fed $5 \mathrm{~g} /$ tank in the morning and $10 \mathrm{~g} /$ tank in the afternoon (32.08 kg/ha/day). Because survival when feeding was initiated was unknown and because survival under these novel culture conditions could not be projected, fish could not be fed at a specific percent body weight/day; therefore, it was decided to feed at a rate that was thought to be greater than $3 \%$ body weight/day so that fish growth in all tanks would not be limited by lack of feed. A total of $800 \mathrm{~g}$ of feed $(1,710.9 \mathrm{~kg} / \mathrm{ha})$ was added to each tank during the yield trial. Both feed and source tank water were added to the tanks from 16 August-9 September.

\section{Assessing growth}

Growth was to be assessed by three monthly samples and at harvest. However, the third monthly sample was not taken because of a behavioral health issue (see below). Consequently, growth was assessed after one and two months and at harvest. Fish were sampled on 16 July (one month [40 days]) and 15 August (two months [70 days]); both times, 30 fish from each tank were measured to the nearest millimeter (TL) and weight was taken to the nearest $0.01 \mathrm{~g}$. Fish were returned to the tanks. Fish were harvested on 15-16 October (131 days), and 50 fish from each tank were measured to the nearest millimeter and weight was taken to the nearest $0.01 \mathrm{~g}$. All other fish were enumerated to determine survival, and a group weight was taken to determine yield.

\section{Behavioral anomaly}

The third monthly sample in September was abandoned and water quality assessments were halted after 30 August, because an unusual behavioral syndrome was noticed, which eventually lead to low levels of chronic mortality. Affected fish, which were dubbed "spinners," had trouble orienting themselves and would swim on one side or on their back. When efforts were made to catch symptomatic fish with a dip net, they swam vigorously, but erratically (often with a corkscrew motion), away from the net. Spinners would attempt to eat feed, but had trouble swimming to the feed and, if they did reach the feed, they erratically swam through it. Symptomatic fish were necropsied, but a pathogenic cause could not be determined. The syndrome was observed in all tanks, but there were only a few symptomatic fish at any given time. Because of this syndrome, the September sample was abandoned so 
that the stress of sampling would not make the situation worse.

\section{Data analysis}

Length and weight from the two samples and length, weight, survival, percent taggable (as a percentage of harvest number), yield, and water quality parameters were assessed by ANOVA, and differences among the treatments were assessed for significance $(P=0.05)$ by Duncan's multiple range test using SAS software version 9.3 of the SAS System for Windows 7 (SAS Institute, Inc., Cary, NC, USA).

\section{Results and Discussion}

Mean lengths and weights and survival for the three treatments are shown in Table 1. Mean length and weight for the three treatments were significantly different $(P=0.05)$ at one month and at harvest; at two months, mean lengths and weights for the 500 and 1,000 fish/tank treatments were not significantly different, but both were significantly larger than the 1,500 fish/tank treatment. As expected, observed mean lengths and weights throughout the study were inversely related to stocking rate.

Lengths and weights in all treatments at one month were considered to show acceptable growth rate and, because of that, feeding was not started. Lengths and weights in all treatments were similar to those observed in one-month-old fish that were received from Dexter in 2010 (Hutson et al., 2012) and in one-month-old fish raised in the naturalized outdoor refugium in 2011 (Tave and Hutson, 2011).

Growth rate slowed during the second month of the yield trial, and fish were only marginally larger at the second sample than they were at the one-month sample. The need to switch from fertilizer only to fertilizer and feed occurred shortly after the one-month sample. Because U.S. Fish and Wildlife Service only permitted us to sample the fish monthly, we were not able to make the decision to switch to feed until after the second sample.

Because the fish that are raised at this facility will be stocked in the Middle Rio Grande, they must be tagged. Taggablesized fish are $\geq 35 \mathrm{~mm} \mathrm{TL}$, so one goal of this project was to determine the percentage of taggable-sized fish (as a percent- age of survival) per treatment (Table 2). Almost all of the fish in the 500 and 1,000 fish/tank treatments were taggable. Even though the observed percent taggable fish in the 1,500 fish/ tank treatment was far lower, it was not significantly different than that of the other two treatments; the reason was due to large variances within treatments.

Had we been able to sample biweekly, it is likely that feeding would have started 14 days after the 16 July sample, and there would have been 16 additional days of feeding. Mean daily growth rate during the 61-day feeding period was 0.332 $\mathrm{mm}$ in the $500 \mathrm{fish} /$ tank treatment, $0.293 \mathrm{~mm}$ in the $1,000 \mathrm{fish} /$ tank treatment, and $0.282 \mathrm{~mm}$ in the $1,500 \mathrm{fish} /$ tank treatment. Thus, it was possible to estimate that mean harvest length for the three treatments would have been $5.31 \mathrm{~mm}, 4.69 \mathrm{~mm}$, and $4.51 \mathrm{~mm}$ greater, and that harvest means would have been $50.96 \mathrm{~mm}, 47.30 \mathrm{~mm}$, and $42.86 \mathrm{~mm}$, respectively, had feeding started 16 days earlier. Harvest SD for length for each treatment was used, along with treatment projected mean harvest length, to estimate the percent taggable fish that would have been produced had feeding started earlier. This was determined by using the estimated means and harvest SD's to calculate the percentile ranking of a $35-\mathrm{mm}$ fish. It was estimated that percent taggable would have increased to $97 \%$ in the $500 \mathrm{fish} / \operatorname{tank}$ treatment, $94 \%$ in the 1,000 fish/tank treatment, and $83 \%$ in the 1,500 fish/tank treatment, had feeding started $16 \mathrm{~d}$ earlier (percent taggable was rounded down to the whole number).

Daily feeding rate (percent body weight/d) at the end of the study was estimated from the biomass in each tank. Daily feeding rates were $4.65 \%$ in the $500 /$ tank treatment, $3.16 \%$ in the $1,000 /$ tank treatment, and $3.50 \%$ in the $1,500 /$ tank treatment. These feeding rates suggest that feed was not a limiting factor in this study.

One of the goals of the project was to determine if growth of fish in tanks at these stocking densities would be similar to that observed in the naturalized outdoor refugium, which is managed using conservation aquaculture management; i.e., production is based only on the use of fertilizers. Harvest means of the three treatments were intermediate between those obtained in the naturalized outdoor refugium in 2010 and 2011. In 2010, ten thousand fish were stocked in the naturalized outdoor refugium (90,909/ha) and, at harvest, mean length was $49.0 \mathrm{~mm}$, mean weight was $1.12 \mathrm{~g}$, survival was

Table 1. Mean \pm SD for length (total length) $(\mathrm{mm})$ and weight $(\mathrm{g})$ at sample 1 (40 days), sample 2 (70 days), and at harvest (131 days) for Rio Grande silvery minnow stocked at 500/tank, 1,000/tank, and 1,500/tank

\begin{tabular}{|c|c|c|c|c|c|c|}
\hline & \multicolumn{2}{|c|}{ Sample 1} & \multicolumn{2}{|c|}{ Sample 2} & \multicolumn{2}{|c|}{ Harvest } \\
\hline & Length & Weight & Length & Weight & Length & Weight \\
\hline 500 & $24.53 \pm 2.42^{\mathrm{a}}$ & $0.14 \pm 0.04^{\mathrm{a}}$ & $25.37 \pm 4.04^{\mathrm{a}}$ & $0.15 \pm 0.08^{\mathrm{a}}$ & $45.65 \pm 8.28^{a}$ & $0.94 \pm 0.46^{\mathrm{a}}$ \\
\hline 1,000 & $22.58 \pm 2.24^{b}$ & $0.12 \pm 0.04^{\mathrm{b}}$ & $24.73 \pm 2.76^{\mathrm{a}}$ & $0.14 \pm 0.05^{\mathrm{a}}$ & $42.61 \pm 6.82^{b}$ & $0.74 \pm 0.35^{\mathrm{b}}$ \\
\hline 1,500 & $20.74 \pm 1.84^{\mathrm{c}}$ & $0.09 \pm 0.03^{\mathrm{c}}$ & $21.13 \pm 2.99^{\mathrm{b}}$ & $0.09 \pm 0.04^{\mathrm{b}}$ & $38.35 \pm 8.19^{c}$ & $0.55 \pm 0.37^{\circ}$ \\
\hline
\end{tabular}

Means followed by different letters were significantly different $(P=0.05)$. 
$58.9 \%$, and yield (harvest biomass/area) was $59.99 \mathrm{~kg} / \mathrm{ha}$ (Hutson et al., 2012). In 2011, twenty-three thousand fish were stocked in the naturalized outdoor refugium (209,090/ha) and, at harvest, mean length was $36.6 \mathrm{~mm}$, mean weight was 0.36 g, survival was $24.1 \%$, and yield was $22.6 \mathrm{~kg} / \mathrm{ha}$ (Tave and Hutson, 2011). The likely reason for the difference in harvest size of fish from the two years in the naturalized outdoor refugium was age and size of fish at stocking; in 2010, fish were 42- to 43-day-old and averaged $21.7 \mathrm{~mm}$, while they were 4-day-old and averaged $5 \mathrm{~mm}$ in 2011. Fish in this yield trial were of similar age and size at stocking as those raised in the naturalized outdoor refugium in 2011, and growth was greater. Fish in this yield trial were smaller at harvest than those from the naturalized outdoor refugium in 2010, but the fish in 2010 were much older and larger at stocking. While these comparisons cannot be exact, they suggest that the growth achieved in this yield trial was acceptable.

Yield is shown in Table 2. Yield was greatest in the 1,000 fish/tank treatment and lowest in the 500 fish/tank treatment, and the difference was significant. Yield in the 1,500 fish/ tank treatment was intermediate and did not differ statistically from the other two. Yield was an order of magnitude greater in all three treatments than those that have been achieved in

Table 2. Mean \pm SD for percent survival, percent taggable (percent of harvested fish $\geq 35 \mathrm{~mm}$ total length), and yield (kg/ha) for Rio Grande silvery minnow stocked at 500/tank, 1,000/tank, and 1,500/tank

\begin{tabular}{rccc}
\hline & Survival (\%) & Taggable (\%) & Yield (kg/ha) \\
\hline 500 & $70 \pm 12^{\mathrm{a}}$ & $86 \pm 24^{\mathrm{a}}$ & $672.5 \pm 121.3^{\mathrm{a}}$ \\
1,000 & $64 \pm 17^{\mathrm{a}}$ & $89 \pm 10^{\mathrm{a}}$ & $1,026.6 \pm 142.2^{\mathrm{b}}$ \\
1,500 & $52 \pm 27^{\mathrm{a}}$ & $65 \pm 22^{\mathrm{a}}$ & $887.8 \pm 288.9^{\mathrm{a}, \mathrm{b}}$ \\
\hline
\end{tabular}

Means followed by different letters were significantly different $(P=0.05)$. the naturalized outdoor refugium, which were $59.99 \mathrm{~kg} / \mathrm{ha}$ in 2010 (Hutson at al., 2012) and $22.6 \mathrm{~kg} / \mathrm{ha}$ in 2011 (Tave and Hutson, 2011). Greater yields were achieved in this study due to higher stocking rates and because the fish were fed.

Even though observed mean survival rates were inversely related to stocking rates, the differences were not significant (Table 2); the reason was due to large variances within treatments. Because Rio Grande silvery minnow is an endangered species, U.S. Fish and Wildlife Service gives a take (maximum permitted mortality) prior to each project, and it was $60 \%$ for this yield trial; overall survival was $59.32 \%$ (take was $40.68 \%$ ), so take was not exceeded.

Water quality among treatments was similar (Table 3 ) and there were no differences $(P=0.05)$, so it is unlikely that water quality accounted for differences in growth or survival among the treatments.

Management used to culture 500 and 1,000 fish/tank was effective in producing taggable-sized fish with acceptable survival. These treatments produced an average of 350 and 640 fish/tank, respectively, and most of the fish were taggable. Further research is needed to determine the number that can be produced without feed. The stocking rates used at the BioPark and at Dexter equate, respectfully, to 356 and 117 fish/tank, which suggest that 100-250 fish/tank might be the stocking rate that could be used to raise fish by using only fertilizers. Based on the survival rate of the 500 fish/tank treatment, these stocking numbers would yield 70-175 taggable fish/tank.

\section{Acknowledgements}

We thank Page Pegram, Grace Haggerty, and Linda Tenorio for assistance in the field and Ken Ferjancic (HDR, Inc.) and Grace Haggerty for reviewing the manuscript. Fish were

Table 3. Mean \pm SD for dissolved oxygen, temperature, $\mathrm{pH}$, un-ionized ammonia, nitrite, alkalinity, chloride, and Secchi disc visibility in the three treatments where Rio Grande silvery minnow were stocked at 500/tank, 1,000/tank, and 1,500/tank

\begin{tabular}{lccc}
\hline Parameters and permitted range & $\mathbf{5 0 0} / \mathbf{t a n k}$ & $\mathbf{1 , 0 0 0 / \text { tank }}$ & $\mathbf{1 , 5 0 0 / \text { tank }}$ \\
\hline Morning & & & $7.14 \pm 0.82$ \\
Dissolved oxygen $(\geq 5 \mathrm{mg} / \mathrm{L})$ & $7.17 \pm 0.85$ & $23.5 \pm 1.9$ & $23.7 \pm 1.2$ \\
Temperature $\left(5-33^{\circ} \mathrm{C}\right)$ & $23.6 \pm 1.2$ & $8.77 \pm 0.90$ & $8.74 \pm 0.18$ \\
pH $(6.5-9.0)$ & $8.69 \pm 0.23$ & & $8.77 \pm 0.89$ \\
Afternoon & & $8.68 \pm 0.90$ & $25.8 \pm 1.32$ \\
Dissolved oxygen $(\geq 5 \mathrm{mg} / \mathrm{L})$ & $8.74 \pm 1.38$ & $25.6 \pm 1.34$ & $8.78 \pm 0.19$ \\
Temperature $\left(5-33^{\circ} \mathrm{C}\right)$ & $25.5 \pm 1.67$ & $8.74 \pm 0.21$ & $0.01 \pm 0.02$ \\
pH $(6.5-9.0)$ & $8.72 \pm 0.19$ & $0.01 \pm 0.02$ & $0.01 \pm 0.01$ \\
Un-ionized ammonia $(<0.5 \mathrm{mg} / \mathrm{L})$ & $0.01 \pm 0.01$ & $0.00 \pm 0.01$ & $2.4 \pm 0.9$ \\
Nitrite $(<1.5 \mathrm{mg} / \mathrm{L})$ & $0.00 \pm 0.01$ & $2.5 \pm 1.1$ & $154 \pm 30$ \\
Chloride $(<250 \mathrm{mg} / \mathrm{L})$ & $2.4 \pm 0.9$ & $155 \pm 32$ & $57.33 \pm 14.33$ \\
Alkalinity $(\geq 100 \mathrm{mg} / \mathrm{L})$ & $147 \pm 30$ & $62.98 \pm 13.88$ & \\
Secchi disc $(>20 \mathrm{~cm})$ & $63.65 \pm 13.56$ & & \\
\hline
\end{tabular}

Differences among treatments for all water quality parameters were not significant $(P=0.05)$. 
cultured under USFWS Permit TE169770-5 and NM Department of Game and Fish Permit 3417. Funds for operations and maintenance of the Los Lunas Silvery Minnow Refugium are provided by Grant Agreement No. 08-FG-40-2803 from the U.S. Bureau of Reclamation.

\section{References}

Boyd CE. 1990. Water Quality in Ponds for Aquaculture. Alabama Agricultural Experiment Station, Auburn University, AL, US.

Caldwell CA, Barrows FT, Ulibarri M and Gould WR. 2010. Diet optimization of juvenile Rio Grande silvery minnow. N Am J Aquac 72, 57-64. http://dx.doi.org/10.1577/A09-011.1.

Hutson AM, Toya LA and Tave D. 2012. Production of the endangered Rio Grande silvery minnow, Hybognathus amarus, in the conser- vation rearing facility at the Los Lunas Silvery Minnow Refugium. J World Aquac Soc 43, 84-90. http://dx.doi.org/10.1111/j.17497345.2011.00537.x

Tave D and Hutson AM. 2011. 2011 Annual Report: USFWS TE Permit 169770-4. Los Lunas Silvery Minnow Refugium, Los Lunas, NM, US.

Tave D, Haggerty G, Medley CN, Hutson AM and Ferjancic KP. 2011. Los Lunas silvery minnow refugium: a conservation hatchery. World Aquac 42(2), 28-34, 67.

Tave D, Valenzuela L, Toya L and Hutson AM. 2012. New design for airlift pump used in fish culture tanks with the endangered Rio Grande silvery minnow (Hybognathus amarus). Croat J Fish 70, 83-91.

U.S. Fish and Wildlife Service. 2010. Revised Rio Grande silvery minnow (Hybognathus amarus) recovery plan. U.S. Fish and Wildlife Service, Albuquerque, NM, US. 